\title{
Cr(III)-Tetraaza Macrocyclic Complexes Containing Auxiliary Ligands (Part I); Synthesis and Characterization of Cr(III)-Benzoato and Chlorobenzoato Macrocyclic Complexes
}

\author{
Jong Chul Byun, " Goo Cheul Kim, and Chung Hun Han \\ Department of Chemistry, Research Instithe for Basic Sciences, Chein National University, Jeju 690-756, Korea \\ Received December 10, 2003
}

\begin{abstract}
The reaction of cis-[Cr([14]-decanc) $\left.\left(\mathrm{OH}_{2}\right)_{2}\right]^{+}$([14]-decane - rac-5,5,7,12,12,14-hexamethyl-1,4,8,11terazacyclotetradecane) with auxiliary ligands $\left\{\mathrm{L}_{a}-\right.$ benzoate(bz) or chlorobenzoate(cbz) $\}$ leads to a new compound $\left[\mathrm{Cr}([14]\right.$-decane $\left.)(\mathrm{bz})_{2}\right] \mathrm{ClO}_{4}$ or $\left[\mathrm{Cr}([14]\right.$-decane $\left.)(\mathrm{cb} z)_{2}\right] \mathrm{ClO}_{4}$. These complexes have been characterized by a combination of elemental analysis, conduclivity, $I R$ and $V$ is spectroscopy, mass spectrometry, and X-ray crystallography. The crystal structure of $\left[\mathrm{Cr}([14] \text {-decane })(\mathrm{cb} z)_{2}\right]^{+}$was determined. The complex shows a distorted octahedral coordination environment with the macrocycle adopting a folded cis-V conformation. The angle $\mathrm{N}_{\text {axial }}-\mathrm{Cr}-\mathrm{N}_{\text {axial }}$ deviates by $14.5^{\circ}$ from the ideal value of $180^{\circ}$ for a perfect octahedron. The bond angle cis-O-Cr-O between the $\mathrm{Cr}(\mathrm{III})$ ion and the two carboxylate oxygen atoms of the monodentate $p$-chlorobenzoate ligands is close to $90^{\circ}$. The FAB mass spectra of the cis-[Cr([14]decanc $\left.)\left(\mathrm{L}_{3}\right)_{2}\right] \mathrm{ClO}_{4}$ display peaks due to the molecular ions $\left[\mathrm{Cr}([14]-\mathrm{decanc})(\mathrm{bz})_{2}-\mathrm{H}\right]^{+},\left[\mathrm{Cr}([14]-\mathrm{decanc})(\mathrm{cb})_{2}\right)_{-}$ $2 \mathrm{H}]^{+}$al $m /=578,646$, respeclively.
\end{abstract}

Key Words : Macrocycle, Cr([l]) complexes, Chlorobenzoate ligand, Crystal structure

\section{Introduction}

Considerably interest exists in the successlul application of the modified 1,4,8,11-1etraazacyclotetradecane cyclam. which can be used as models for a protein-metal binding site in biological systems ${ }^{1-3}$ and as selective reagents of metallic ions. ${ }^{4-6}$ The DNA binding of Cr-macrocyclic complexes is an area of great interest and activity, since these cleavage reagents potentially can be used for cancer therapy or as resiriction nucleases. ${ }^{j-9}$

In recent years there have been many investigations of the synthesis, struclures, and propertics of various types of $\mathrm{N}$ functionalized tetraaza macrocyclic ligands and their transition metal complexes. ${ }^{16-12}$ In particular, the reactivity of nickel- or cobalt-macrocyclic complexes toward Lewis bases like oxalate has been explored in detail. ${ }^{1 \hat{-1}-1 ?}$ Eriksen and cowokers recently attempled to characterize the complex formation between carboxylic acids/carboxylates in particular acelic acid/acelate and macrocyclic chromium complexes excmplified by cis complexes of rac-5,5,7,12,12,14hexamethyl-1,4,8.11-terazacyclotetradecane $\left(\mathrm{L}_{\mathrm{t}}-|14|-\right.$ decane) and cyclam. ${ }^{18}$ IJowever, much less attention has been given to the synthesis of the corresponding $\mathrm{Cr}$ macrocyclic complexes containing auxiliary ligands. ${ }^{19}$

In the present study, we describe the preparation and isolation of cis- $\mid \mathrm{Cr}(|14|$-decane $)\left(\mathrm{L}_{\mathrm{a}}\right)_{2} \mid \mathrm{ClO}_{4}\left\{\mathrm{~L}_{\mathrm{i}}-\right.$ benzoato<smiles>CNC(C)CC(C)(C)NC(C)CC(C)NCCNC(C)C</smiles>

$\left.r a c^{\prime}-\mid 14\right]-d e c a n e$

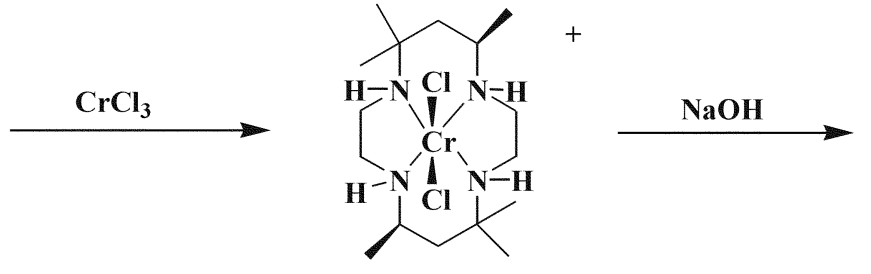

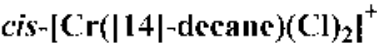

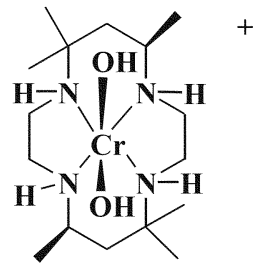

cis- $\left[\mathrm{Cr}(\mid 14]-\left.(\mathrm{lecanc})(\mathrm{OH})_{2}\right|^{3+}\right.$

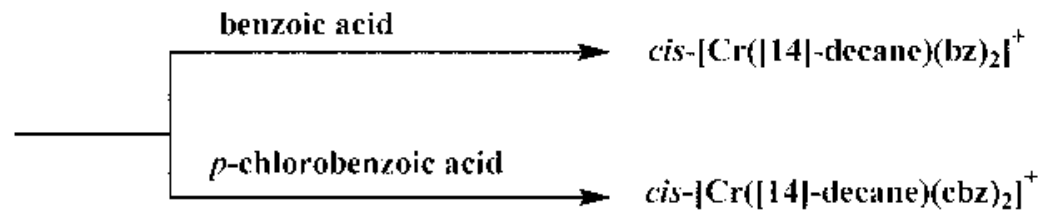

Scheme 1. Synthetic route of the eis- $\mid \mathrm{Cr}\left(|14|-\mathrm{decan}^{2}\right)\left(\mathrm{L}_{i}\right)$ ) $\mid$. 
$\left(\mathrm{br} \mathrm{z}^{-}\right)$, chlorobenzoato $\left(\mathrm{cb} 7^{-}\right)$) (Scheme 1$)$ and present the $\mathrm{X}$ ray structure of the chlorobenzoato complex as well as the elemental and spectra analysis of benzoato and chlorobenzoato complexes. We have taken considerable interest in investigating the crystal structure of the complexes formed by $\mathrm{Cr}$ (III) and rac-form, [14]-decane with auxiliary ligands in cis position. These compounds are considered as quite attractive transition metal-macrocyclic complexes containing cis ligands, such as cisplatin, with antitumor activity.

\section{Experimental Section}

Measurements. Flemental microanalyses were performed using a l.F.CO CHN-900 analyzer. The electronic absorption spectra of the complexes were acquired in DMF at $25^{\circ} \mathrm{C}$. using a HP model 8453 UV-VIS spectrophotometer. Conductivity measurements were carried out in DMF at $25=$ $1{ }^{\circ} \mathrm{C}$, using an ORION 162 conductivity temperature meter. IR spectra were recorded using $\mathrm{KBr}$ pellets on a Bruker FSS66 FT-IR spectrometer. FAB-mass spectra were obtained on a JГOI. JMS-700 Mass Spectrometer, using argon $(6 \mathrm{kV}$, $10 \mathrm{~mA}$ ) as the FAB gas. The accelerating voltage was $10 \mathrm{kV}$, and glycerol was used as the matrix. The mass spectrometer was operated in positive ion mode and mass spectra were calibrated by Alkali-Csl positive.

Preparation of starting materials. The $r a c$-[14]decane, ${ }^{20.21}$ cis-[Cr([14]-decane $\left.)(\mathrm{Cl})_{2}\right] \mathrm{Cl}$, and cis-[Cr([14]decane $\left.)(\mathrm{OH})_{2}\right]^{-}$solutions ${ }^{18.22}$ were prepared according to the literature procedure.

Preparation of cis-|Cr(|14|-decane) $(\mathrm{bz})_{2} \mid \mathrm{ClO}_{4}+0.5 \mathrm{H}_{2} \mathrm{O}$. cis-[Cr([14]-decane $\left.)(\mathrm{OH})_{2}\right]^{-}$solution $(50 \mathrm{ml})$ was acidified with benzoic acid $(9 \mathrm{~g})$ in methanol $(20 \mathrm{ml})$. To this was added a saturated aqueous $\mathrm{NaClO}_{4}$ solution $(20 \mathrm{ml}$.) with stirring for $2 \mathrm{~h}$ under reflux, and the solution was allowed to stand at room temperature until a pink precipitate formed. The precipitate was filtered, washed twice with methanol and ether and dried in vacuo Yield: 34\%. Anal. Calcd (Found) \% for $\mathrm{C}_{31} \mathrm{H}_{46} \mathrm{~N}_{4} \mathrm{O}_{8} \mathrm{ClCr} 0.5 \mathrm{H}_{2} \mathrm{O}: \mathrm{C}, 52.44$ (52.65): $\mathrm{H}, 6.89(6.96) ; \mathrm{N}, 8.15(8.22) . \Lambda_{\mathrm{N}}$ (in DMF): $67.0 \mathrm{ohm}^{-1}$ $\mathrm{cm}^{2} \mathrm{~mol}^{-1}$.

Preparation of $c i s-\left|\mathrm{Cr}(|14|-d e c a n e)(\mathrm{cbz})_{2}\right| \mathrm{ClO}_{4}$. cis$\left[\mathrm{Cr}([\mathrm{d}] \text {-decane })(\mathrm{OH})_{2}\right]^{-}$solution $(10 \mathrm{~mL})$ was acidified with a $p$-chlorobenzoic acid (1.6 g) dissolved in methanol $(40 \mathrm{~mL})$. The mixture was refluxed for $1 \mathrm{~h}$. A saturated aqueous $\mathrm{NaClO}_{4}$ solution ( $4 \mathrm{~mL}$ ) was added to the above hot solution. The resulting mixture was stirred for $2 \mathrm{~h}$ under reflux and then cooled to room temperature. The pink precipitate was filtered, washed twice with methanol and ether and dried in vacuo. Yield: $50 \%$. Anal. Caled (Found) $\%$ for $\mathrm{C}_{3 j} \mathrm{H}_{44} \mathrm{~N}_{4} \mathrm{O}_{3} \mathrm{Cl}_{3} \mathrm{Cr}$ : C. 48.23 (48.29); H, 5.94 (6.06); N, $7.50(7.57) . \Lambda_{\mathrm{v}}$ (in DMr): $67.1 \mathrm{ohm}^{-1} \mathrm{~cm}^{2} \mathrm{~mol}^{-1}$.

Crystal Structure Determination, Crystals of cis$\left[\mathrm{Cr}([\mathrm{l})]\right.$-decane) $\left.(\mathrm{cbz})_{2}\right] \mathrm{ClO}_{4}$ suitable for $\mathrm{X}$-ray diffraction study were grown from an acetonitrile: $\mathrm{H}_{2} \mathrm{O}(\mathrm{l}: 1)$ solution of the complex. A pink crystal of complex was mounted on a glass fiber and coated with epoxy resin. The single crystal data for the complex were collected on an Kappa CCD diffractometer equipped with graphite-monochromated Mo K $\alpha$ radiation $(\lambda=0.71073 \AA$ ). The crystallographic data, conditions for the collection of intensity data, and some features of the structure refinements are listed in Table 1. The intensity data were corrected for L orentz and polarization effects. Absorption correction was not made during processing. Of the 7999 unique reflections measured, 7913 were considered to be observed $(F>4 \sigma(F))$ and were used in subsequent structure analysis. The structure was solved by the direct method ${ }^{2:}$ and refined by full-matrix least-squares refinement with use of the SHEI,XI - -97 package program. ${ }^{24}$ All non-hydrogen atoms were refined anisotropically. All hydrogen atoms except for the water hydrogen atoms were placed in the calculated positions with isotropic displacement parameters.

Crystallographic data for the structure reported here have been deposited with Cambridge Crystallographic Data Center (Deposition No. CCDC-236172). The data can be

Table 1. Cry stallographic Data for cis-[Cr([14]-dceanc)(cbz) $]\left(1 O_{4}\right.$

\begin{tabular}{|c|c|}
\hline Formulit & $\mathrm{C}_{30} \mathrm{II}_{4+} \mathrm{N}_{4} \mathrm{O}_{8} \mathrm{Cl}_{3} \mathrm{Cr}$ \\
\hline Formula teight & 747.04 \\
\hline Radiation $(\dot{A})$ & Mo K(0.71073) \\
\hline Crystal system & orthorhombic \\
\hline Space group & Pbea \\
\hline$a(A)$ & $12.0930(10)$ \\
\hline$b(A)$ & $20.3580(10)$ \\
\hline$c(\lambda)$ & 28.852 \\
\hline$\alpha\left({ }^{\circ}\right)$ & 90 \\
\hline$\beta\left({ }^{*}\right)$ & 90 \\
\hline$\gamma\left({ }^{\circ}\right)$ & 90 \\
\hline $1(3)$ & $7103.1(7)$ \\
\hline$\%$ & 8 \\
\hline$f(\mathrm{~K})$ & $293(2)$ \\
\hline$D_{\text {calis }}\left(g_{\mathrm{g} \mathrm{cm}}^{-3}\right)$ & 1.397 \\
\hline$u\left(\mathrm{~mm}^{-1}\right)$ & 0.600 \\
\hline no. unjique data & 7999 \\
\hline no. of obsd data $\left(F_{13}>4 \sigma\left(F_{11}\right)\right)$ & 7913 \\
\hline no. variable & 422 \\
\hline Goodness of tit & $\mathrm{I} .127$ \\
\hline$R$ (abs. all) & 0.0977 .0 .2172 \\
\hline$R_{w}($ obs. a $\left.]\right)$ & 0.1620 .0 .3278 \\
\hline
\end{tabular}

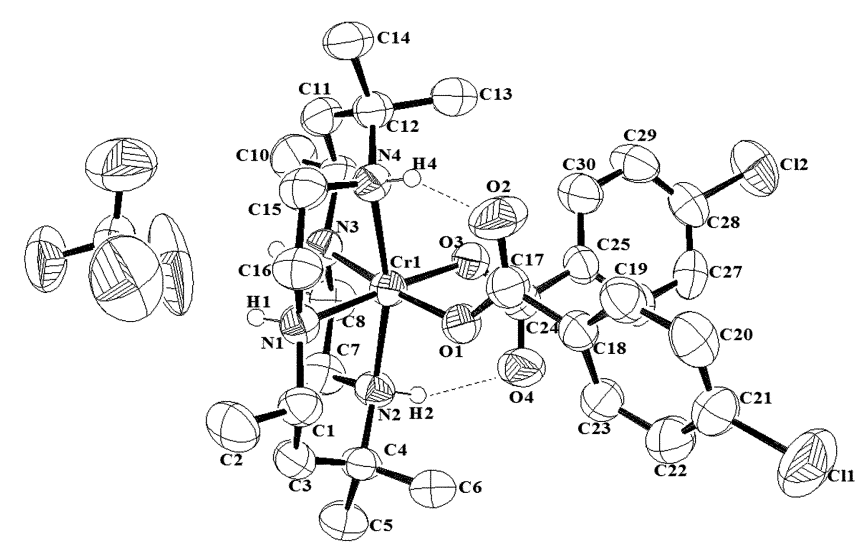

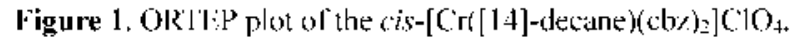


obtained free of charge via www.cedc.cam,ac.uk/conts retrieving.htm] (or from the CCDC, 12 Union Road. Cambridge CB2 1Г.7., UK; fax: +44 1223336033 ; e-mail: deposit( 0 cedc.cam.ac.uk).

\section{Results and Discussion}

Crystal Structure. An ORTIP drawing of the cis$\left[\mathrm{Cr}([14]\right.$-decane $\left.)(\mathrm{cb} 7)_{2}\right] \mathrm{ClO}_{4}$ with the atomic labeling scheme is depicted in Figure 1. The selected bond distances and angles are listed in Table 2 and 3. The crystal structure of the present complex consists of monomeric cation of the indicated formula and noninteracting perchlorate anion. The monomeric cation, $\left[\mathrm{Cr}([14]-\text { decane })(\mathrm{cb} 7)_{2}\right]^{+}$shows a distorted octahedral enviromment, where the chromium(III) ion is coordinated by secondary amines of the macrocycle and by the two carboxylate oxygen atoms of the monodentate $p$ chlorobenzoate ligands in cis positions. The rac-form. [14]decane readily folds to give cis-chromium(1l]) complexes with the (RRRR, SSSS) sec-NH configuration and two equatorial and one axial methyl substituents on each sixmembered chelate ring. Therefore, two chlorobenzoates are bonded to the chromium(II) by monodentate ligand rather than single chlorobenzoate bonding by bidentate, forming a sterically stable six-coordinate complex. Here, the chlorobenzoate acted as bidentate ligand, forming a four-membered ring, over straining the structure, whereas the two chlorobenzoates function as a monodentate ligand, resulting in a more preferable structure.

The oxygen atoms from the chlorobemzoate ligands and two nitrogen donors (positions of $(-$ methyl group) of the [14]-decane define the equatorial coordination plane $\left(\mathrm{CrN}_{2} \mathrm{O}_{2}\right.$ $x y$-plane). Hexa-coordination is accomplished via the remaining two nitrogens of macrocyclic ligand (positions of C-dimethy group) 1. The tetra-aza ligand is folded along the $\mathrm{N}(2)-\mathrm{Cr}-\mathrm{N}(4)$ axis (axial position). This configuration is often referred to as the Bosnich type- $\mathrm{V}$ stereochemistry. ${ }^{25} \mathrm{~A}$ similar type of configuration was reported for cis$[\mathrm{Cr} \text { (cyclam) } \mathrm{Cl}(\mathrm{dmso})]^{2-} .20$ The $\mathrm{Cr}-\mathrm{N}$ (secondary amines) bond distances are in the range of $2.115(5)-2.140(5) \dot{A}$. and $\mathrm{Cr}-\mathrm{O}$ (p-chlorobenzoate) distances are 1.964(4) $\AA$ and $1.973(4) \AA^{27.20}$ (lable 2). The bond angles are $\mathrm{N}(\mathrm{I})-\mathrm{Cr}-\mathrm{N}(3)$.

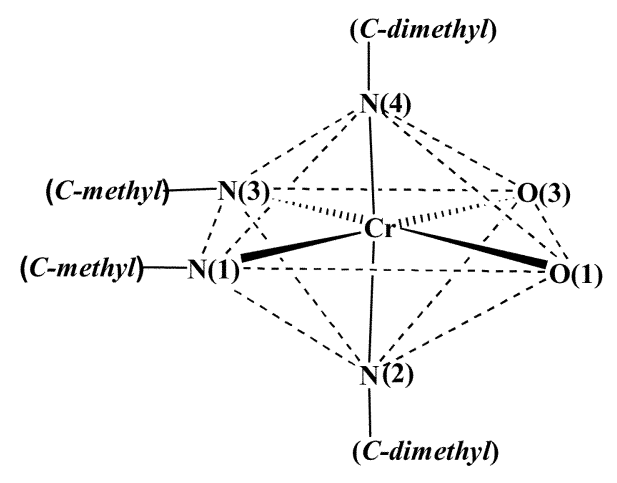

Table 2. Sclected bond lengths $(\AA)$ for cis- $[\mathrm{Cr}([14]$-dceane)$\left.(\mathrm{cbs}) \mathrm{h}_{2}\right] \mathrm{C} / \mathrm{O}_{+}$

\begin{tabular}{|c|c|c|c|}
\hline $\operatorname{Cr}(1)-O(1)$ & $1.964(4)$ & $\operatorname{Cr}(1)-O(3)$ & $1.973(4)$ \\
\hline $\operatorname{Cr}(1)-N(1)$ & $2.115(5)$ & $\operatorname{Cr}(I)-\mathrm{N}(2)$ & $2.140(5)$ \\
\hline $\operatorname{Cr}(1)-N(3)$ & $2.118(5)$ & $\operatorname{Cr}(1)-N(4)$ & $2.131(5)$ \\
\hline$(17)-O(2)$ & $1.232(7)$ & $C(24)-O(4)$ & $1.238(7)$ \\
\hline$C(17)-O(1)$ & $1.297(7)$ & $C(24)-O(3)$ & $1.288(7)$ \\
\hline$x(2) \cdots \lambda(4)$ & $2.721(7)$ & $O(4) \cdots N(2)$ & $2.791(7)$ \\
\hline
\end{tabular}

Table 3. Selected bond angles $\left({ }^{\circ}\right)$ for cis-[Cr([14]-decane)$(\mathrm{cbz})_{2} \mid \mathrm{C} 1 \mathrm{O}_{4}$

\begin{tabular}{llll}
\hline$O(1)-\operatorname{Cr}(1)-O(3)$ & $89.2(2)$ & $\mathrm{N}(1)-\mathrm{Cr}(1)-\mathrm{N}(4)$ & $82.8(2)$ \\
$O(1)-\operatorname{Cr}(1)-\mathrm{N}(1)$ & $87.7(2)$ & $\mathrm{N}(3)-\mathrm{Cr}(1)-\mathrm{N}(4)$ & $87.7(2)$ \\
$O(3)-\operatorname{Cr}(1)-\mathrm{N}(1)$ & $176.5(2)$ & $\mathrm{O}(1)-\mathrm{Cr}(1)-\mathrm{N}(2)$ & $97.9(2)$ \\
$O(1)-\mathrm{Cr}(1)-\mathrm{N}(3)$ & $173.9(2)$ & $\mathrm{O}(3)-\mathrm{Cr}(1)-\mathrm{N}(2)$ & $91.7(2)$ \\
$O(3)-\mathrm{Cr}(1)-\mathrm{N}(3)$ & $84.8(2)$ & $\mathrm{N}(1)-\mathrm{Cr}(1)-\mathrm{N}(2)$ & $87.3(2)$ \\
$\mathrm{N}(1)-\mathrm{Cr}(1)-\mathrm{N}(3)$ & $98.4(2)$ & $\mathrm{N}(3)-\mathrm{Cr}(1)-\mathrm{N}(2)$ & $83.3(2)$ \\
$O(1)-\mathrm{Cr}(1)-\mathrm{N}(4)$ & $92.3(2)$ & $\mathrm{N}(4)-\mathrm{Cr}(1)-\mathrm{N}(2)$ & $165.5(2)$ \\
$O(3)-\operatorname{Cr}(1)-\mathrm{N}(4)$ & $98.8(2)$ & & \\
& & & \\
$O(2)-1(4)-\mathrm{N}(4)$ & $153.5(2)$ & $O(4)-\mathrm{H}(2)-\mathrm{N}(2)$ & $145.6(2)$ \\
\hline
\end{tabular}

$\mathrm{N}(2)-\mathrm{Cr}-\mathrm{N}(4)$ and $\mathrm{O}(1)-\mathrm{Cr}-\mathrm{O}(3) 98.4(2)^{\circ}, 165.5(2)^{\circ}$ and $89.2(2)^{\circ}$, respectively (Table 3 ). These values are well within the general trend with those found in the cis-forms of other tetraaza macrocyclic complexes of $\operatorname{Cr}($ III $){ }^{26}$ An accepted fact is that in cis octahedral complexes of macrocycles of medium size (12-14 membered rings) the pattern of metalligand distance and the angle between the axial donors and the metal center are particularly affected by the cavity size. ${ }^{\text {in }}$ In this complex, $\mathrm{Cr}-\mathrm{N}(1 ; 2.115(5) \AA)$ and $\mathrm{Cr}-\mathrm{N}(3 ; 2.118(5)$ $\bar{A})$ distances are shorter than $\mathrm{Cr}-\mathrm{N}(2$, axial; $2.140(5) \AA)$ and $\mathrm{Cr}-\mathrm{N}(4$, axial; $2.131(5) \AA)$ and the angle $\mathrm{N}(2)-\mathrm{Cr}-\mathrm{N}(4)$ $\left(165.5(2)^{\circ}\right)$ is smaller than the ideal value of $180^{\circ}$, indicating that the donor atoms cannot achieve the axial positions of a perfect octahedron. By contrast, in cis-[Cr(cyclam) $\left.\mathrm{X}_{2}\right]$ octahedral complexes, the angle $\mathrm{N}_{\text {axial }}-\mathrm{Cr}-\mathrm{N}_{\text {asial }}$ is closer to $180^{\circ}$ than that of the title complex and the axial and equatorial distances have similar values." ${ }^{2}$ "The distances and angles were found to be $\mathrm{O}(2) \cdots \mathrm{N}(4) 2.72 \mathrm{I}(7) \AA, \mathrm{O}(2)-\mathrm{H}(4)-\mathrm{N}(4)$ $153.5(2)^{\circ} ; \mathrm{O}(4) \cdots \mathrm{N}(2) 2.791(7) \AA$, and $\mathrm{O}(4)-\mathrm{H}(2)-\mathrm{N}(2)$ $145.6(2)^{\circ}$, which reflect a hydrogen bonding $2^{31.32}$ Under this situation, the self-organization seems to make the structure 2 more stable by the hydrogen bonding interaction. in which the carboxylate oxygen $O(1)$ of $p$-chlorobenzoate anion is coordinated to the central $\mathrm{Cr}(\mathrm{III})$ and $\mathrm{O}(2)$ is $\mathrm{H}$ bonded with $\mathrm{H}(4)$ to form a six-membered ring.

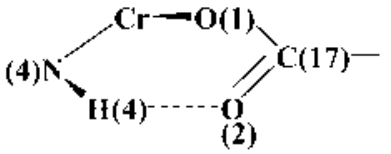


Electronic Absorption Spectra. The absorption spectra of cis-[Cr([14]-decane) $\left.(\mathrm{br})_{2}\right]^{+}$complex ion in DMF solution at room temperature is represented in Figure 2. Table 4 summarizes the electronic spectral data of cis-[Cr([14]decane $\left.)(\mathrm{br})_{2}\right]^{+}$, cis- $\left[\mathrm{Cr}([14]-\text { decane })(\mathrm{cbz})_{2}\right]^{+}$, and $\left[\mathrm{CrN}_{4^{-}}\right.$ $\left.\left(\mathrm{L}_{\mathrm{a}_{2}}\right]_{2}\right]^{1-}$ chromophores. There are overlapping absorption parts in the spectrum of the title complexes, including the two distinct bands. In $O_{k}$ symmetry, three ligand field bands are expected for a $d^{3}$ ion ${ }^{4} A_{2 \xi} \rightarrow{ }^{1} T_{2 \mathrm{~g}},{ }^{1} A_{2 \xi} \rightarrow{ }^{1} T_{1 g}(\mathrm{~F})$ and the two electron transition ${ }^{4} A_{2,} \rightarrow{ }^{1} T_{12}(\mathrm{P}) .{ }^{33}$ The two $d-d$ bands of title complexes observed at $18200,25390 \mathrm{~cm}^{-1}$ can be related to the spin-allowed transitions, ${ }^{4} A_{2 k} \rightarrow{ }^{~} T_{24}$ and ${ }^{~}{ }^{\prime} A_{24}$ $\rightarrow{ }^{\prime} T_{1}$, respectively. The assignment of geometric configuration is confirmed by the $d-d$ absorption spectra. The less symmetrical cis-isomers have much higher extinction coefficients than those of more symmetrical trans-isomers. ${ }^{3.1}$

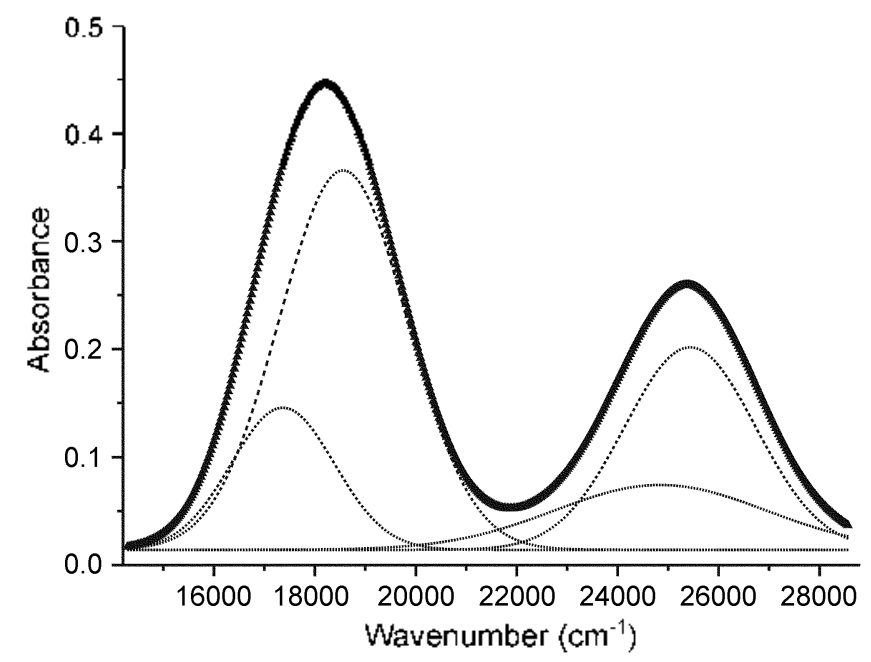

Figure 2. The electronic absorption spectrum of cis-[Cr(|l4]decane $\left.)(h \%)_{2}\right] \mathrm{ClO}_{4} 0.5 \mathrm{H}_{2} \mathrm{O}$ in DMF solution at $298 \mathrm{~K}$.
Table 4. Electronic transition spectral data of several $\mathrm{Cr}-$ macrocyclic complexes

\begin{tabular}{|c|c|}
\hline Complexes & $v \cdot \mathrm{cm}^{-1}\left(\varepsilon \cdot \mathrm{M}^{-1} \mathrm{stl}^{-1}\right)$ \\
\hline trats-[Cr(cyclam $\left.) C l_{2}\right]^{+a}$ & 17483(19.9). 24570(35). 27397(41) \\
\hline $\operatorname{arans}-\left[\operatorname{Cr}(m e s o-[14]-\mathrm{dccanc}) \mathrm{Cl} l_{2}\right]^{-b}$ & $17422(25) .22727(27) .25840(47)$ \\
\hline wats- $\left[\mathrm{Cr}(m e s o-[14]-\mathrm{dccanc}) \mathrm{Br}_{2}\right]^{-h}$ & $16667(33) .24390(38) .26178(43)$ \\
\hline $\operatorname{cis}-\left[\mathrm{Cr}(\mathrm{cyclam}) \mathrm{Cl}_{2}\right]^{-"}$ & $18904(111) .24752(106)$ \\
\hline $\operatorname{cis}-\left[\mathrm{Crt}([14]-\mathrm{dccanc})\left(\mathrm{NO}_{3}\right)_{2}\right]^{+h}$ & $19084(202) .25641(116)$ \\
\hline$c i s-\left[\operatorname{Crt}([14]-d w c a n c)(b z)_{2}\right]^{-}$ & $18236(223) .25394(131)$ \\
\hline $\operatorname{cis}-\left[\mathrm{Crt}[[14]-d c c a n c)(\operatorname{chz})_{2}\right]^{-}$ & $18265(221) .25394(127)$ \\
\hline
\end{tabular}

"taken from ref. 35 . "taken from ref. 34.

Chromium complexes in tetragonal symmetry are expected to have four absorption bands in the $d$ - $d$ region, but each spectrum apparently has two major components. Thus, we

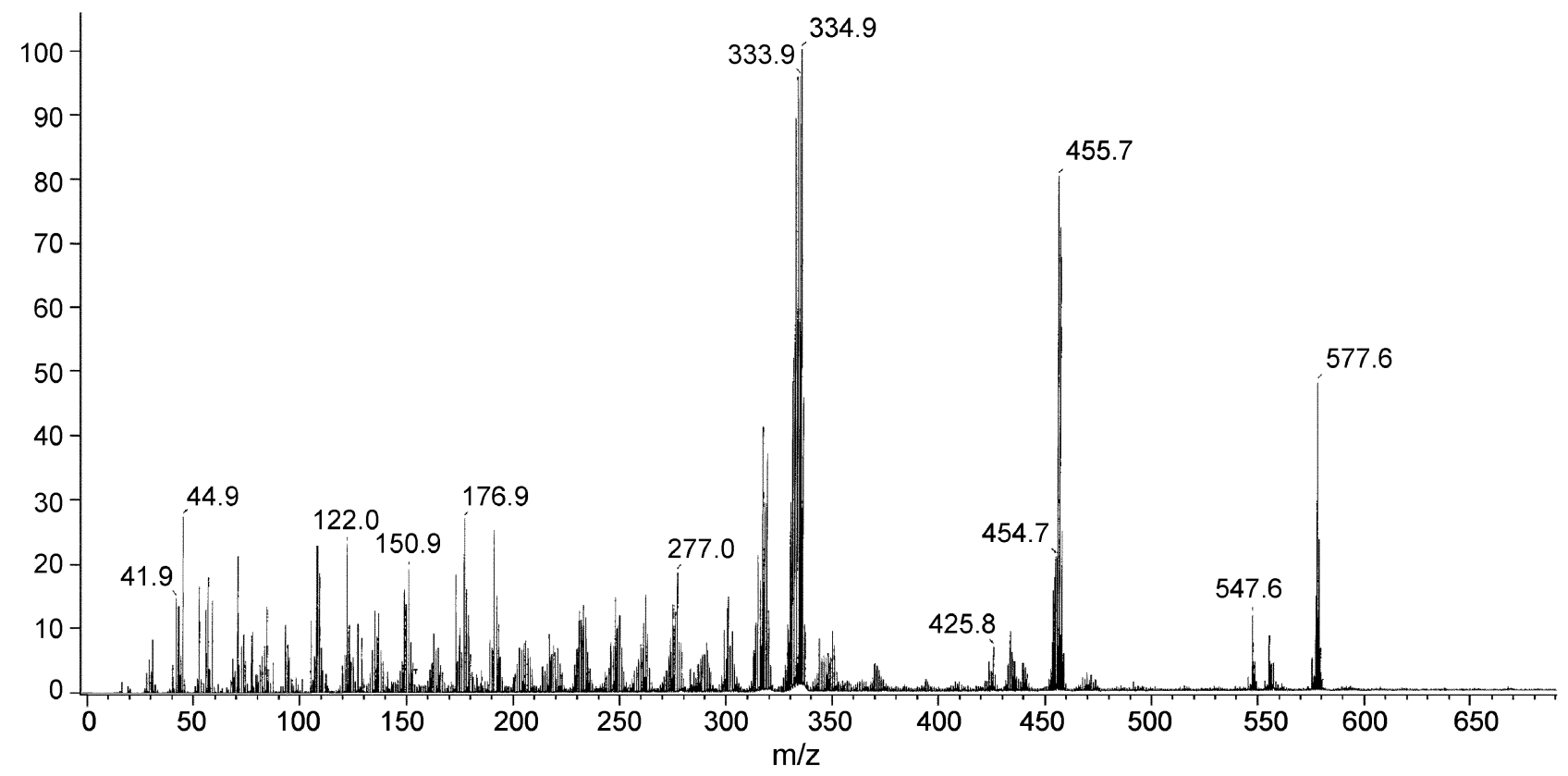

Figure 4. The $\mathrm{l} / \mathrm{AB}$ mass spectrum of the cis- $\left|\mathrm{C}(\mathrm{r}|\mathrm{l}| \mathrm{|} \mid \mathrm{decane})(\mathrm{bz})_{2}\right| \mathrm{C} \mid \mathrm{O} \cdot 0.5 \mathrm{l}_{2} \mathrm{O}$. 


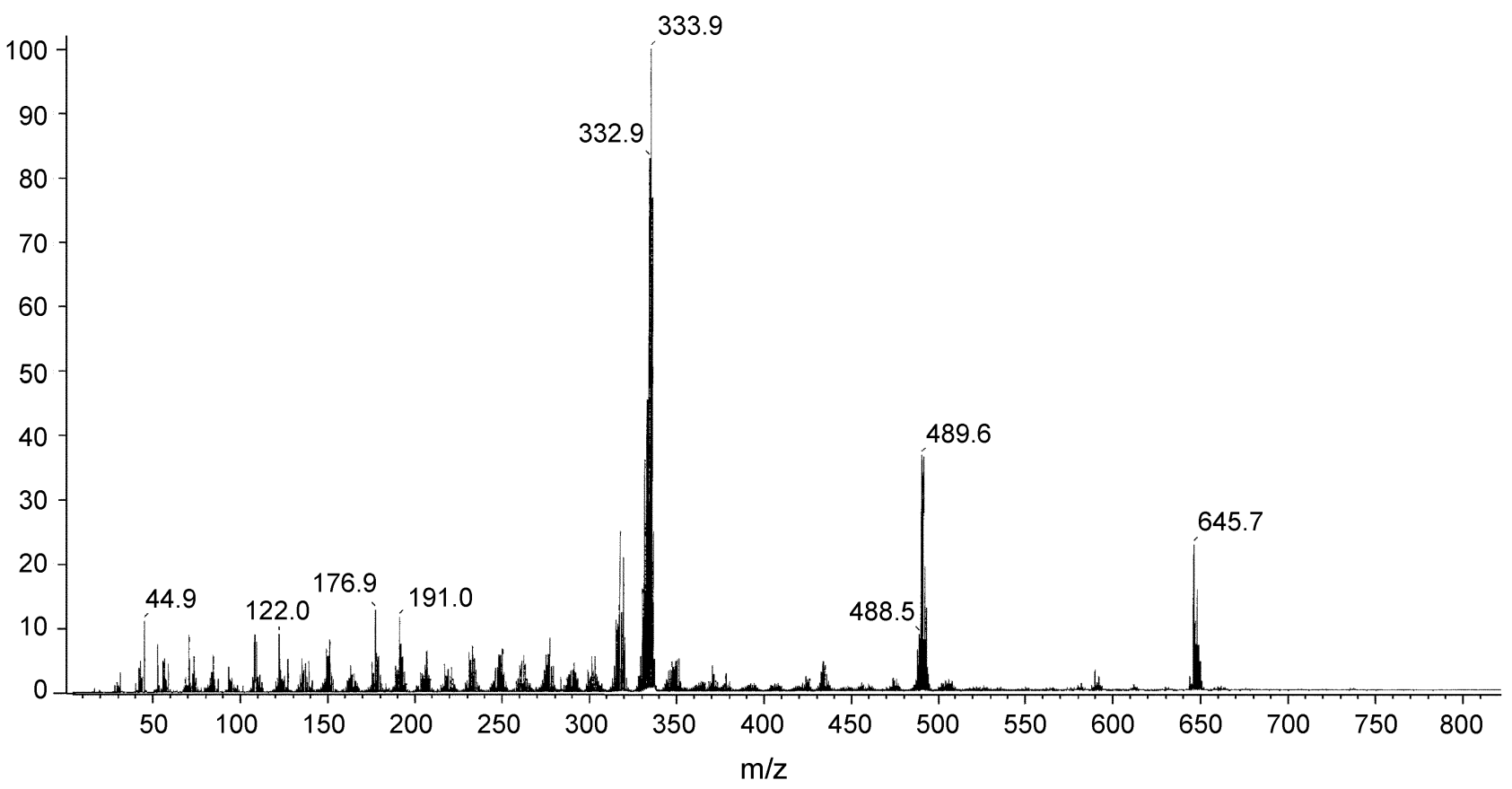

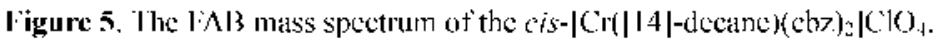

and then added a minor component to reproduce the more suitable shape of the spectra in the region of interest. Finally, we performed least-squares fitting procedures, and the dotted lines in Figure 2 are Gaussian bands representing the approximate deconvolution of the spectra yielded by the calculations. The four peak positions calculated at 17364 , 18562,24848 and $25438 \mathrm{~cm}^{-1}$ can be assigned to the ${ }^{4} \mathrm{~F}$. $\left({ }^{+} \mathrm{T}_{2 \mathrm{~g}}\right.$ in $\mathrm{O}_{4}$ symmetry), ${ }^{4} \mathrm{~B}_{2}\left({ }^{4} \mathrm{~T}_{2 \mathrm{~g}}\right),{ }^{4} \mathrm{~F}\left({ }^{+}{ }^{\mathrm{T}} \mathrm{T}_{\mathrm{gg}}\right)$ and ${ }^{4} \mathrm{~A}_{2}\left({ }^{4} \mathrm{~T}_{\mathrm{lg}}\right)$, respectively. ${ }^{36.37}$ Similar procedures are also applied to $\mathrm{cis}$ $\left[\mathrm{Cr}([14] \text {-decane })(\mathrm{cbz})_{2}\right]^{-}$, taken 17644, 18853,25052 and $25524 \mathrm{~cm}^{-1}$.

Infrared and mass spectra. Three main features are observed in the IR spectra of the new two Cr(III) complexes: (1) The vibrations due to antisymmeric $-\mathrm{NH},-\mathrm{CH}$, and $\mathrm{Cr}-\mathrm{N}$ stretching mode in the macrocycle appear at ca. 3205.2973. $474 \mathrm{~cm}^{-1}$, respectively, and are common to two complexes. ${ }^{38,39}$ (2) In the title complexes, bands due to $v_{\mathrm{as}}$ (COO${ }^{-}$; antisymmetric mode) and $v_{\mathrm{s}}\left(\mathrm{COO}^{-}\right.$; symmetric mode $)$of coordinated carboxylate (donor atom: $O$ ) occur at $1609 \mathrm{~cm}^{-1}$ and $-1367 \mathrm{~cm}^{-1}$. Unidentate carboxylate complexes have much greater values, $\Delta v\left\{-v_{\mathrm{ss}}\left(\mathrm{COO}^{-}\right)-v_{\mathrm{s}}\left(\mathrm{COO}^{-}\right)\right.$; bezonate: $242 \mathrm{~cm}^{-1}$, $p$-chlorobezoate: $\left.257 \mathrm{~cm}^{-1}\right\}$ than the ionic carboxylate..$^{+0}(3)$ The very strong absorption at near -1120 $\mathrm{cm}^{-1}$ and $-624 \mathrm{~cm}^{-1}$ are assigned to ionic perchlorate (Figure 3)..$^{40 .+1}$ The values of molar conductance for cis-[Cr([14]decane $\left.)\left(\mathrm{L}_{\mathrm{a}}\right)_{2}\right] \mathrm{C}$. 10 , measured in D.MF or DMSO correspond to a $1: 1$ electrolyte $\left(\Lambda_{\mathrm{N}}-67.0 \mathrm{ohm}^{-1} \mathrm{~cm}^{2} \mathrm{~mol}^{-1}\right)$, indicating that the auxiliary ligands in the $\mathrm{Cr}(\mathrm{I}] \mathrm{I})$ complexes are not dissociated from the complex in these polar solvents. ${ }^{42}$

In the $\mathrm{FAB}$ mass spectra of $\left[\mathrm{Cr}([14]\right.$-decane $\left.)(\mathrm{bz})_{2}\right] \mathrm{ClO}_{4}$ and $\left[\mathrm{Cr}([14]\right.$-decane $\left.)(\mathrm{cbz})_{2}\right] \mathrm{ClO}_{4}$ there is a peak at $m / z 578$. 646 corresponding to the molecular ions [ $\mathrm{Cr}([14]$-decane)$\left.(\mathrm{bz})_{2}-\mathrm{H}\right]^{-}$. [Cr([14]-decane)(cbz) $\left.)_{2}-2 \mathrm{H}\right]^{-}$, respectively (Figure
4 and 5). The molecular ion of the cis-[Cr([14]-decane)(b7.) $)_{2} \mathrm{ClO}_{1}$ and cis-[Cr([14]-decane)(cb7) $\left.)_{2}\right] \mathrm{ClO}_{1}$ undergoes fragmentation to give species such as $[\mathrm{Cr}([14]-$ decane $)(\mathrm{b} 7)$ $2 \mathrm{H}]^{+},[\mathrm{Cr}([14]-\text { decane })-\mathrm{H}]^{-}$and $[\mathrm{Cr}([14]-\text { decane })(\mathrm{cb} 7)-2 \mathrm{H}]^{+}$, $[\mathrm{Cr}([14] \text {-decane })-2 \mathbf{H}]^{+}$at $m / z 456,335$ and $m / z 490,334$, respectively.

\section{References}

1. Kimura, Г.: koike. Т. Advances' in Inorganic Chemist?; Academic l'ress: New York, 1996; vol 44.

2. Kimura. E.: Koike. I.: Shionoya. M. Stmat. Bond. 1997. 89. 1.

3. Kimura. E.: Koike. T. Chem. Commun. 1998, 1495.

4. Blain. S.: Apprioul. P.: Chammeil. H.; Handel. H. Anal. Chm. Acta 1990, 232, 331

5. Tsubuke. 11: Yoden. T.: 7enki, V. J. Chem. Soc. Chem. Commm. 1991, 1069 .

6. Kimura. E.: Koiks. I. Chem. Soc. Rev. 1998, 27, 179.

7. Bakac. A.: Wang, W. Inorg. Chm teta 2000, 297. 27.

8. Aromnguiri, A.: Maya, B. G. Inory Chem 1996. 35.4267.

9. Parand $\Lambda$; Royer $\Lambda$. C.: Cantrell. T. I..; Crowder. M. W. Inorg. Chm. Acte 1998, 268.211.

I0. Amrbein. I' I.: Lough. A. I.: Morris. R. II. Morg Chem. 1996, 35. 4523 .

I1. Chi. T.: Pariya C.: Chung. C. Inorg Chim Acta 1999. 285. 107.

12. Choi, K.: I.ec. H.; Kim, J. horg. Chim. Acta 2001, 321. 221.

13. Szalda, D. I.: Fujita, F.: Filias, I I. Inorg. (Them. 1904, 33.5855.

14. Curtis, N. F. /norg. Chm Atte 2001, 3/7, 27.

15. Kim, I. Cho, J.; Lough. A. J. Anotg. Chim. Acta 2001. 3/7. 252.

16. Hirola, S.: Polson. S. M.: Moore, S. I.: Marzilli, L. G. Inorg. Chem. 1996. 35. 5646.

17. Kang. S: Ryu K.: Kim. J. Bull Kurean Chem. Soc 2002, 23,81.

18. Frikisen. I.: Monsted. I.: Mensted, O. Inorg. Chim Aota 2002. 337,143 .

19. Leo, M. A. D : Bu, X: Bentow J : Ford. P. C. Inorg. Chint Acta 2000, 300-302,944

20. Curtis. N. F. f. Chem. Soc 1964. 2644.

2I. Hay, R. W.: Curtis. V. F. J. Chem. Soc: Perkin/1964. 2644. 
22. Eriksen. J.: Monsted. O. Acta Chem. Scamd 1983. A37. 579.

23. Sheldrick. G. M. Acta Grestallogr: 1990. A46.467.

24. Sheldrick. G. M. SHELIZ-97. Program for the Refinentent of Cinstal Structures: University of Göttingen: Gemmanv. 1997.

25. Bosnich, B.: Poon, C. K. Tobe. M. L. Inorg Chent 1965 t. 1102.

26. Felix. V: Santos. T. M.: Calhorda. M. J. horg. Chim. Acta 2003. 356.335 .

27. Choi. J. H.: Suzuki. T.: Subhan. Md. A.: Kaizaki. S.: Park. Y. C. Acta Crost 2002 , C58, 17409.

28. Choi J. H. Suzuki, T.: Kaizaki. S Acta Cnest 2002, C58, m539.

29. House, D. A: Steel P. J. Inorg Chim Acta 1998. 269. 229.

30. Hodgson. D. J.: Pedersen. E.: Tottlund. H.: Weiss. C. horg (Chm. Acta 1986. 120.177.

31. Domasevitch. K. V: Ponomareva. V. V: Rusanov. E. B. Inorg. Chim. Acta 1998, 268,93.

32. Choi, K. Y; Kim, M. J; Hong, C. P. Bull Korean Chem. Soc.
2002. 23.1062.

33. Kane-Maguire. N. A. P.: Wallace. K. C.: Miller. D. B. horg Chent $1985,24,597$.

34. House, D. A.; Hay, R. W: Ali, M. A. horg Chim. Acta 1983. 72. 239.

35. Ferguson. J.: Tobe. M. L. Jhorg Chim Acta 1970. f. 109.

36. Dubicki. L.: Day. P. Inorg. Chem. 1971. 10. 2043.

37. Swisher. R. G.: Brown. R. C.: Smierciak. R. C.: Blinn. E. L. Inorg. Chem. 1981. 20. 3947.

38. Choi. J. H. Spectrochin. Acta 2000, 56.4. 1653.

39. Choi. J. H. Chem. Phus 2000, 256, 29.

40. Nakamoto. K. Infrared and Raman Spectra of Inorganic and Coordination Compounds. Part B: Tohn Wiley \& Sons: New York. 1997.

41. Poon. C. K.: Pun, K. C. Inong Chent 1980. 19, 568.

42. Geary, W. J. Coord Chent Ren: 1971, 7,81. 